\title{
Spinal Dorsal Meningioma Spinal Dorsal Meningiom
}

\author{
Hakan Sercan KURTOĞLU, Selçuk YAVUZ, Nurettin TAŞTEKIN, Murat BIRTANE \\ Department of Physical Medicine and Rehabilitation, Trakya University Faculty of Medicine, Edirne, Turkey
}

\begin{abstract}
Meningiomas are usually benign, slow-growing tumors that originate from arachnoid cap cells. Spinal meningiomas represent $12 \%$ of all meningiomas. They tend to grow slowly and cause different symptoms, depending on the region affected; therefore, the time between the onset of symptoms and diagnosis is variable. Before the frequent use of magnetic resonance imaging (MRI), some cases with spinal meningiomas were reported to be operated on with a misdiagnosis of lumbar disc herniation or knee disorder. Here, we report a case of a patient who had been operated on with the diagnosis of lumbar spinal stenosis but had complaints of weakness in the legs and difficulty walking. The patient did not improve after the operation. Further investigations after the surgery revealed that the patient had spinal meningioma.

Key Words: Meningioma, spinal stenosis, spine tumor
\end{abstract}

Özet

Meningiomlar; araknoid hücrelerden köken alan, tipik olarak selim karakterde, yavaş büyüyen tümörlerdir. Tüm meningiomlar içerisinde spinal meningiomlar \%12 sıklıkta görülmektedir. Genellikle yavaş büyüme eğiliminde olmaları ve bulundukları bölgeye göre farklı semptom oluşturmaları nedeniyle semptomların başlamasıyla tanı konulması arasında geçen süre değişkendir. Manyetik rezonans (MR) görüntüleme öncesinde bazı spinal meningiomlu olguların lomber disk hernisi veya diz cerrahisi geçirdikleri bildirilmiştir. Burada 67 yaşında uzun süredir bel ağrısı ve alt ekstremitede ilerleyici kas gücü kaybı olan, lomber spinal stenoz tanısıyla opere edildikten sonra dorsal meningiom tanısı alan bir hastayı sunduk. Ameliyat sonrası tarafımıza başvuran hastayı rehabilitasyon amacıyla servisimizde takip ettik.

Anahtar Kelimeler: Meningiom, spinal stenoz, omurilik tümörü

\section{Introduction}

Meningiomas are usually benign, slow-growing tumors that originate from arachnoid cap cells (1). Spinal meningiomas represent $12 \%$ of all meningiomas (2). The most frequently involved localization is the thoracic region, followed by the cervical and lumbar regions $(3,4)$. Spinal meningiomas are typically located in the intradural extramedullary space (5).

They tend to grow slowly and cause different symptoms, depending on the region affected; therefore, the time between the onset of symptoms and diagnosis is variable (6).

Magnetic resonance imaging (MRI) is the best non-invasive technique to prevent a misdiagnosis (7). Before the frequent use of
MRI, some cases with spinal meningiomas were reported to be operated on with a misdiagnosis of lumbar disc herniation or knee disorder (6). Spinal meningiomas lead to chronic spinal cord compression and myelopathy. Treatment is predominantly surgical (8).

Here, we report a case of a patient who had been operated on with the diagnosis of lumbar spinal stenosis but had complaints of weakness in the legs and difficulty walking. The patient did not improve after the operation. Further investigations after the surgery revealed that the patient had spinal meningioma.

\section{Case Report}

A 67-year-old woman with low back pain, complaints of weakness in the lower extremities, and difficulty walking was admit- 
ted to a neurosurgical outpatient clinic. She had been suffering from mechanical low back pain for 15 years. She walked without support until 1 year ago. Then, she had gradually increasing lower extremity muscle weakness. Previously, she could walk 20 meters without stopping with a single cane, which she has not managed to do during the last year, needing a walker. Numbness and tingling did not accompany the weakness in the legs. Informed consent was taken from the patient to report the clinical progress.

Magnetic resonance imaging of the lumbar spine demonstrated relative spinal stenosis at the L2-3, L3-4, and L4-5 levels, and the patient had been operated on with a diagnosis of spinal stenosis. After the surgery, her pain was alleviated and she could walk with a single cane, but she could not walk without a walker in the following days. The patient was examined for a probable malignancy after she became immobile. Lumbar and cervical MRI, brain computed tomography, and whole-body bone scan findings were within the normal range. Computed tomography of the thorax revealed an intradural extramedullary mass, approximately $2 \mathrm{~cm}$ in diameter, at the T5-6 level (Figure 1). The patient was operated on with a pre-diagnosis of spinal meningioma, and the diagnosis was confirmed by the pathology report.

The patient was bedridden when she was admitted to our clinic. Maintenance of balance in the short or long sitting position was intact. We could not obtain detailed neurological examination records from before the surgery. The physical examination findings done after the surgery in our department were as follows: lower extremity muscle strength: hip flexors $(\mathrm{R} / \mathrm{L}): 2 / 5,2 / 5$; knee extensors: $4 / 5,4 / 5$; ankle dorsiflexors: $3 / 5,1 / 5$; and toe dorsiflexors and ankle plantar flexors: 2/5, 1/5. She had Ashworth grade II spasticity in the lower left limb's adductors and gastrocnemius muscles. There were sensory deficits in the lower

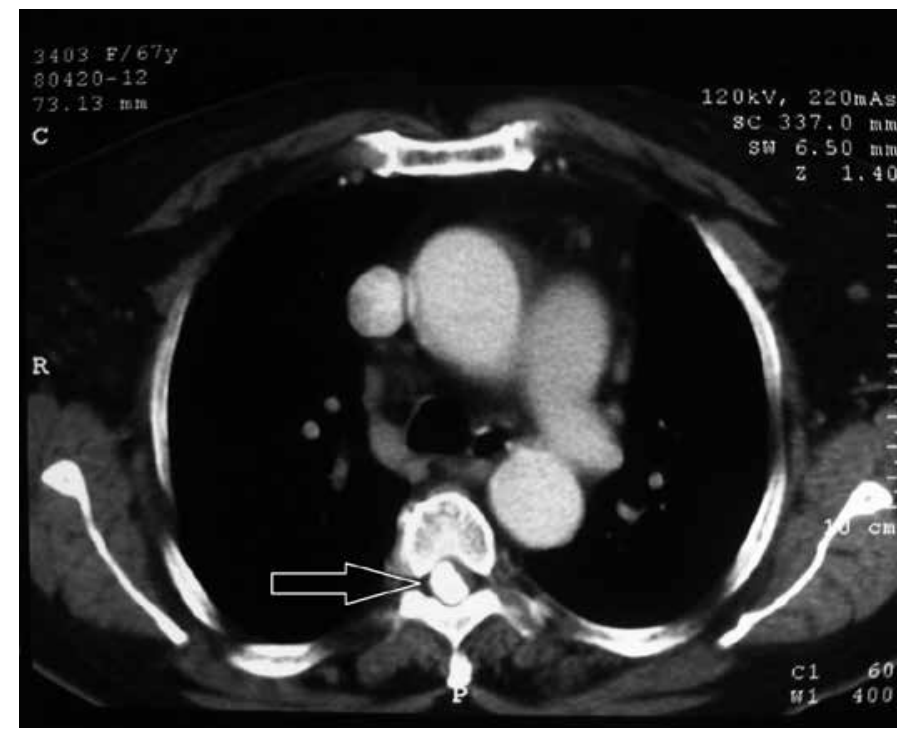

Figure 1. Axial computed tomography of the thorax, showing an approximately 2-cm-diameter intradural extramedullary mass at the T5-6 level (arrow) left limb's L4/5 and S1 dermatomes. The patellar and Achilles tendon reflexes were absent bilaterally. There was a positive Babinski sign on the right foot and an indifferent Babinski sign on the left. There were no bowel or bladder disturbances.

Physical therapy and neurological rehabilitation programs were planned for the patient. Electrical stimulation therapy to the quadriceps and tibialis anterior muscles and range of motion, stretching, and strengthening exercises were prescribed. An ankle-foot orthosis was designed for the left leg. Local cold-pack applications and oral baclofen (30 mg) therapy were started for her spasticity. The dose of gabapentin was increased to $2400 \mathrm{mg}$ gradually, which had been started previously for her neuropathic pain. She started to walk at the parallel bar in the following days. Her final lower extremity muscle strength was as follows: hip flexors (R/L): 4/5, 4/5; knee extensors: 4/5, 4/5; ankle dorsiflexors: $4 / 5,1 / 5$; and toe dorsiflexors and ankle plantar flexors: $3 / 5$, $1 / 5$. Afterwards, the patient was trained and instructed about home exercises and called for regular follow-up visits.

\section{Discussion}

The exact incidence of spinal meningiomas is not known; however, the total incidence of spinal intradural tumors is estimated to be from 3 to 10 per 100,000 persons per year (9). The peak incidence occurs between the sixth and eighth decades of life (10). Spinal meningiomas most often affect women compared with men. The female:male ratio is 3-4:1 (7).

Spinal meningiomas are generally slow-growing benign neoplasms, and patients often have a long clinical history before the meningioma is diagnosed. The mean duration of symptoms prior to presentation is 1 to 2 years. Symptoms vary, depending on the size and location of the tumor (8). Pain is the most frequent symptom. The frequency of radicular, funicular, and localized back-low back pain is $83 \%$. The other frequently associated symptoms observed are paresis, plegia, and anesthesia. A careful differential diagnosis should be performed for multiple sclerosis, syringomyelia, and pernicious anemia and herniated disc in case of a suspicious clinical situation. The radiological evaluation remains very important, as the clinical conditions to be assessed tend to lead serious chronic problems (7).

Computed tomography displays bone deformities better, and psammomatous intratumoral calcification can be seen in spinal meningiomas (11). Magnetic resonance imaging is the best noninvasive neuroimaging technique in preventing a misdiagnosis. An MR image provides exact information about the tumor localization (affected segment, relation to spinal cord and nerve root, and relation of the tumor to the dura), the extent of spinal cord compression, and further information about the spinal cord and the tumor itself (presence of cord edema and intratumoral signal changes, such as necrosis, hematoma, or calcification) (12). Spinal meningiomas are usually isointense to the spinal cord (T1- and T2-weighted MR images) and show homogeneous enhancement after contrast medium (Gd) administration (8). 
The primary goal of surgery is the removal of the tumor completely and safely (13). Electrophysiological monitoring has become a standard procedure in intramedullary tumor surgery (14). Motor and sensory pathways can be affected independently in both the pre-and postoperative periods (15).

The advances in neuroradiological and neurosurgical techniques have enhanced the success in the treatment of spinal meningiomas. Post-surgical clinical findings are closely related with the pre-surgical status of the patient. Treatment success rates are higher in spinal meningiomas that are diagnosed early. So, the prevention of sequellae with an early diagnosis will preclude the resulting disability-related problems and affect quality of life in a positive manner.

Spinal meningiomas most likely involve the dorsal region (55\%). They are more frequent in aged people and may be recognized late in this population with symptoms due to degenerative joint pathologies. For this reason, a detailed neurological examination and whole vertebral imaging must be performed to reveal these pathologies. In this case, the early diagnosis of spinal stenosis in the absence of additional clinical findings caused a delay in the true diagnosis of an advanced neurological pathology.

\section{Conclusion}

A detailed examination of the vertebral column in aged people with probable vertebral pathologies is mandatory to prevent the problems due to comorbid clinical situations.

Informed Consent: Written informed consent was obtained from patient who participated in this study.

Peer-review: Externally peer-reviewed.

Author Contributions: Concept - H.S.K., N.T.; Design - H.S.K., S.Y.; Supervision - M.B., N.T.; Funding - H.S.K., S.Y., M.B., N.T.; Materials - H.S.K.; Data Collection and/or Processing - H.S.K., N.T.; Analysis and/or Interpretation - H.S.K., S.Y., N.T., M.B.; Literature Review - H.S.K., N.T.; Writer - H.S.K., S.Y.; Critical Review - N.T., M.B.; Other - H.S.K., S.Y.

Conflict of Interest: No conflict of interest was declared by the authors.

Financial Disclosure: The authors declared that this study has received no financial support.

Hasta Onamı: Yazılı hasta onamı bu çalışmaya katılan hastadan alınmıştır.

Hakem değerlendirmesi: Dış bağımsız.

Yazar Katkıları: Fikir - H.S.K., N.T.; Tasarım - H.S.K., S.Y.; Denetleme M.B., N.T.; Kaynaklar - H.S.K., S.Y., M.B., N.T.; Malzemeler - H.S.K.; Veri toplanması ve/veya işlemesi - H.S.K., N.T.; Analiz ve/veya yorum - H.S.K.,
S.Y., N.T., M.B.; Literatür taraması - H.S.K., N.T.; Yazıyı yazan - H.S.K., S.Y.; Eleştirel İnceleme - N.T., M.B.; Diğer - H.S.K., S.Y.

Çıkar Çatışması: Yazarlar çıkar çatışması bildirmemişlerdir.

Finansal Destek: Yazarlar bu çalışma için finansal destek almadıklarını beyan etmişlerdir.

\section{References}

1. Lantos PL, VandenBerg SR, Kleihues P. Tumors of the nervous system. In: Graham DI, Lantos PL (eds.). Greenfield's neuropathology. London: Oxford University Press; 1996.p.583-879.

2. Russell DS, Rubinstein LJ. Tumor of the meninges and related tissues. In Russell DS, Rubinstein LJ (eds). Pathology of Tumours of the Nervous System. 5th ed. London: Edward Arnold, 1989.p.449-532.

3. Levy W], Bay J, Dohn D. Spinal cord meningioma. J Neurosurg 1982;57:804-12. [CrossRef]

4. Parry DM, Eldridge R, Kaiser-Kupfer MI, Bouzas EA, Pikus A, Patronas N. Neurofibromatosis 2 (NF2): Clinical characteristics of 63 affected individuals and clinical evidence for heterogeneity. Am J Med Genet 1994;52:450-61. [CrossRef]

5. Frank BL, Harrop JS, Hanna A, Ratliff J. Cervical extradural meningioma:Case report and literature review. J Spinal Cord Med 2008;31:302-5.

6. Cohen-Gadol AA, Zikel OF, Koch CA, Scheithauer BW, Krauss WE. Spinal meningiomas in patients younger than 50 years of age: $A$ 21-year experience. J Neurosurg 2003;98(Suppl 3):258-63.

7. Gezen F, Kahraman S, Canakci Z, Beduk A. Review 36 cases of spinal cord menigioma. Spine 2000;15:727-31. [CrossRef]

8. Setzer M, Vatter H, Marquardt G, Seifert V, Vrionis FD. Management of spinal meningiomas: Surgical results and a review of the literature. Neurosurg Focus 2007;23:E14. [CrossRef]

9. Slooff JL, Kernohan JW, MacCarty CS. Primary Intramedullary Tumors of the Spinal Cord and Filum Terminale Philadelphia, WB Saunders, 1964.

10. Gottfried ON, Gluf W, Quinones-Hinojosa A, Kan P, Schmidt MH. Spinal meningiomas: Surgical management and outcome. Neurosurg Focus 2003;14:6E2.

11. Lee JW, Lee IS, Choi KU, Lee YH, Yi JH, Song JW, et al. CT and MRI findings of calcified spinal meningiomas: Correlation with pathological findings. Skeletal Radiol 2010;39:345-52. [CrossRef]

12. Schroth G, Thron A, Guhl L, Voigt K, Niendorf HP, Garces LR. Magnetic resonance imaging of spinal meningiomas and neurinomas. Improvement of imaging by paramagnetic contrast enhancement. J Neurosurg 1987;66:695-700. [CrossRef]

13. Klekamp ], Samii M. Surgical results for spinal meningiomas. Surg Neurol 1999;52:552-62. [CrossRef]

14. Kothbauer K, Deletis V, Epstein F]. Intraoperative spinal cord monitoring for intramedullary surgery: an essential adjunct. Pediatr Neurosurg 1997; 26:247-54. [CrossRef]

15. Steinbok P, Cochrane DD, Poskitt K. Intramedullary spinal cord tumors in children. Neurosurg Clin N Am 1992;3:931-45. 